\title{
Review on the Role of Parkland Agro Forestry in Agricultural Landscapes of West Africa and Lessons Draw for East Africa
}

\author{
Belayneh Bayu \\ Bahir Dar Environment and Forest Research Center, P.O.Box 2128. Bahir Dar Ethiopia
}

\begin{abstract}
Parkland agroforestry practice can provide different environmental services, especially for biodiversity conservation. This practice gets big attention with agroforestry and conservation scientists. The main purpose of this paper was to explore what are the main ecosystems services and livelihood strategy of parkland agroforestry provide to farming communities in West Africa region and the main challenges faced in conservation and management of the diversity of these trees in agricultural landscapes. What are the best practices and concerns towards parkland agroforestry in West African countries have and what lessons can be drawn to their counterparts in East African farming communities.The contributions and challenges of parkland agroforestry practices were described by different scholars. In West Africa's region parklands as anthropogenic landscapes with a rational land use system developed by farmers over many generations and farmers select and protect tree species to diversify production for subsistence and income as well as to minimize environmental risks related to climatic variability. The contribution to the conservation of biodiversity through in situ conservation of tree species on farm, reduction of pressure on remnant forests, and the provision of suitable habitat for a number of plants and animal species on farmlands. Besides, planted trees and shrubs contribute significantly to farmers' livelihoods by supplying food, fodder, wood and medicine. The main challenges are poor survival rate of seedlings due to moisture stress and browsing, careless field clearing and weeding, and the presence of seedlings seemed to be determined mainly by moisture availability and seed availability. In conclusion parkland in West Africa covers wide part of the agricultural landscapes providing enormous services and products to the farming communities of the region. Then the best practices accumulated in West Africa have to be transfered to East Africa through linking the agroforestry expertes and the farmers of the two regions.
\end{abstract}

Keywords: Biodiversity Consrvation, Ecosystem Service and Antropogenic landscapes

DOI: $10.7176 / \mathrm{JNSR} / 9-13-05$

Publication date:July $31^{\text {st }} 2019$

\section{Introduction}

1.1 Definition of parkland agro forestry

One of the essential strategies to conserve trees biodiversity is dealing with the scattered trees existed in agricultural landscapes. The scattered trees in agricultural landscapes are also known as parkland trees. Many authors defined parklands as scattered multipurpose trees occur in cultivated or fallowed fields (Pullan, 1974; Nair, 1985; Boffa, 1999).Others defined parklands from the ecological and economical perspective: according to Bonkoungou et al (1994), defined the ecological and economical role of parklands in the farming system as" parklands are land-use systems in which woody perennials are deliberately preserved in association with crops and/or animals in a spatially dispersed arrangement and where there is both ecological and economic interaction between trees and other components of the system. The main purpose of this paper was to explore what are the main ecosystems services and livelihood strategy of parkland agroforestry provide to farming communities West Africa region and what are the main challenges faced in conservation and management of the diversity of these trees in agricultural landscapes. What are the best practices and concerns towards parkland agroforestry in West African countries have and what lessons can be drawn to their counterparts in East African farming communities.

\section{How is parkland agroforestry evolved and going on in West Africa?}

Many authors described the West Africa's region parklands as anthropogenic landscapes with a rational land use system developed by farmers over many generations and those farmers select and protect tree species to diversify production for subsistence and income as well as to minimize environmental risks related to climatic variability (Boffa, 1995; Kathrin Schreckenberg, 1999; Boffa, 2000; Maranz and Wiesma, 2003; Bayala et al., 2011; Marius RM Ekué et al, 2010). According to Emilie Smith (2010) farmers have an extensive knowledge of natural regeneration processes and the complex interactions between human and ecological factors affecting different tree resource. Farmers in Benin who noticed the decreasing of wild reserve tree species were making deliberate efforts to plant and conserve on their farmlands (Fifanou et al., 2011).

Farmers have also different traditional and cultural reasons to conserve tree species. For example in Benin a tree species called Ackee (Blighia sapida K.D. Koenig) is integrated in different land use system across the country for a variety of reasons including the direct uses such as food, soap, medicine, shade and apart from the direct uses a combination two or three reasons that determined the conservation of Ackee in farmers 'field. The main 
motivation is always food in one ethnic group, others for medicinal purpose, for its marketing value, soap and shade. Thus, each of the ethnic group had different motivations to conserve the trees of Ackee. In addition, women conserve ackee for soap making and its commercial value (Marius RM Ekué et al., 2010).

Therefore, the Region's farmers have longstanding management experience of parkland agroforestry practices and which shows the implication of sound socio-ecological interaction.

\section{Territorial coverage of parklands in Western Africa}

Parklands occupy a vast land area representing a large part of the agricultural landscape under subsistence farming in the tropics and constituting the predominant agroforestry system in semi-arid West Africa (Nair, 1993; Bonkoungou et al., 1994). In Mali the agroforestry parkland system occupies about 90 percent of the agricultural land area (Kalinganire et al., 2007).

In Burkina Faso, parklands agroforestry are found in low human population area of north, east and southern parts where agriculture is practiced. The parkland system is also recognized as the most common production system in Katsina State in northern Nigeria (Otegbeye and Olukosi, 1993). A discontinuous cover of scattered trees in crop fields is traditional in northern Ghana (Rudat et al., 1996).

\section{Ecosystem services of parkland agroforestry}

\subsection{Provision services and livelihood strategy}

Agroforestry parklands are the most common land use systems in semi-arid zones of West African Sahel where the majority of a predominantly rural population is subsistence farmers.

In the Sahel Parklands are mixtures of trees and shrubs those farmers select for certain functions. Farmers' preference of tree species is dictated by the roles the species plays for fodder production, food production, high quality wood, soil fertility maintenance, medicinal, income generation(Ibrahima D. and Malaïny D. 2004; Fifanou et al., 2011).

They selectively cultivate those trees and shrubs together with staple food crops, such as millet and sorghum and they serve as sources of foods, including fruits, fats, oils, leafy vegetables, nuts and condiments that complement food crops in the local diet (Gunnar Gustad et al., 2004; Belem et al., 2011). Native species of trees and shrubs contribute significantly to farmers' livelihoods by supplying food, medicinal products, fodder, and wood (Faye et al., 2010).

Many products derived from indigenous parkland trees such as Vitellaria paradoxa, Parkia biglobosa, Adansonia digitata and Sclerocarya birrea, provide the most frequently consumed staple food, fruits and drinks (Gunnar Gustad et al, 2004).

According to Faye et al (2010) in Mali,"The products of parkland trees and shrubs that generated the greatest revenue were fruits, wood, and Adansonia digitata leaves, followed by shea butter from Vitellaria paradoxa, P. biglobosa fruits, and shea soap from V. paradoxa and the revenue from the sale these products contributed as much as 73 per cent of the annual household income." And he also confirmed the contribution of parkland agroforestry to farmers` annual revenue in Mali varied from 26 percent up to 73 percent. The products of these non-timber trees are consumed locally, factory-processed or exported.

Particularly worthy of note is the contribution of fruit trees to food security and nutritional balance: 200000 tons of mangoes from engrafted and 50000 tons of fruit from grafted trees are produced each year (Reynes and Odoux, 1999). For instance, mango trade from the Sikasso region Mali showed that 72 percent of the output was locally, $17 \%$ percent was transported to non-mango producing regions and 11 percent was exported (Coulibaly, 1999).

\subsection{Biodiversity conservation}

Traditional agroforestry parkland system practices contribute to the conservation of biodiversity through in situ conservation of tree species on farm, reduction of pressure on remnant forests, and the provision of suitable habitat for a number of plant and animal species on farmland (Fifanou et al., 2011; Atta-Krah et al., 2004; McNeely and Schroth 2006; Acharya, 2006). This diversity will make agroforestry practices more sustainable and productive as well as helping to conserve local biodiversity by supporting farmers in their choices will assist them in their livelihood strategy (Ard GL., 2003).

Parkland agroforestry have also a vital role in regeneration of indigenous tree species and contribute for biodiversity conservation (Figure 1). For instance in Burki nafaso the regeneration of Vitellaria paradoxa, Parkia biglobosa and other species in parkland seedlings was higher under crown than outside (Ræbild et al., 2011).Another survey in Benin also showed that in 100 farmlands covering the natural range of Iroko (Milicia excels) forty-five species belong to 24 plant families were recorded in traditional agroforestry parkland system (Christin and Sokpon, 2008). Thus, the role of traditional agroforestry parkland practices to support tree species richness and provide evidence the farms role as biodiversity reservoirs (Fifanou et al., 2011). 


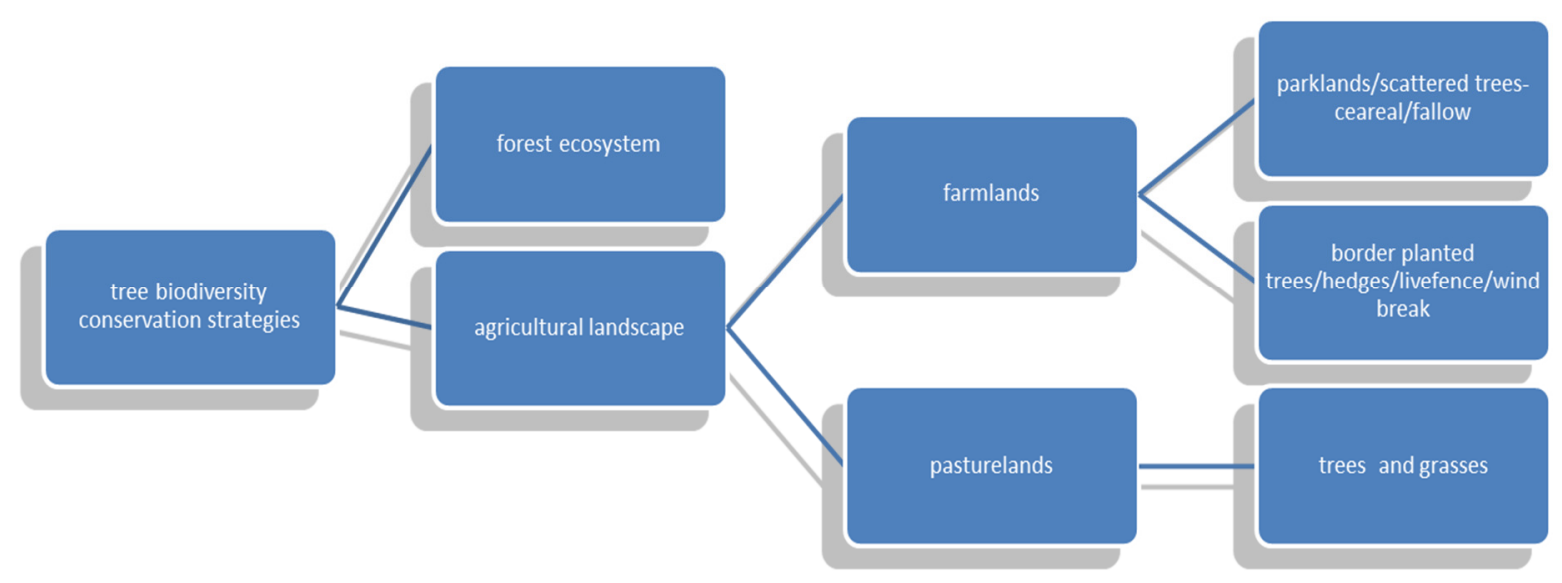

Fig1.Tree diagram of operationalization of tree biodiversity conservation strategies

\subsection{Impact on Microclimate, Soil and Crop Yield}

The other important ecosystem services of parkland trees is that they contribute highly to farmlands soil fertility, conserve soil moisture, lower sunlight intensity, microclimate and some tree species if not all are companion with field crops and enhance yield. For instance in the highlands of Eastern Ethiopia the presence of Acacia albida on farmlands increases the yield of maize (Zea mays L.) and sorghum (sorghum bicolor L.Moench) plots under Acacia albida foliage cover and the plots in open field; an average increment of crop yield by $56 \%$ was found (Peter Poschen, 1986). Other study in Southern Burkina Faso, in parklands of karite (Vitellaria paradoxa) and nere (Parkia biglobosa) trees millet production tree canopies had higher soil fertility (organic matter and potassium) and soil moisture, and lower sunlight intensity than the middle field. Crop grain and biomass production were higher at the edge of medium-sized karite canopies than either under the canopy or at mid-distance between trees.so at least in the short term millet production can be improved by crown pruning of these trees ( Bayala e al., 2002). Likewise according to Jonsson et al. (1998) in Southern Burkinafaso, temperature modification and soil fertility, of nere (Parkia biglobosa) and karite $\hat{A}$ (Vitellaria paradoxa) could exceed the negative effects of these tree species shade on millet (Pennisetum glaucum) production.

\subsection{Climate Change Mitigation}

Parkland trees have high potential of carbon accumulation in their biomass so protecting them has great contribution to prevent global warming. A survey in West Africa Sahel showed traditional parkland agroforestry systems had relatively larger C stock than the improved systems, but they seemed to have only limited potential for sequestering additional $\mathrm{C}$. On the other hand, the improved parkland agroforestry systems showed higher potential for sequestering $\mathrm{C}$ from the atmosphere (Asako et al., 2007). And the traditional parkland agroforestry systems had high C stock in their biomass and soil, (Schroth et al., 2004; Takimoto et al., 2008).

\section{Cultural values and amenities of parkland trees}

Parkland trees used the local community as for handicraft, and medicinal purposes; for instance in Mali of the 20 species, five were used in handicraft production, 11 yielded traditional human foods, and 11 had medicinal uses (Gunnar Gusted et al., 2004).

5.1. Handicraft: species recorded in the market of Cinzana (Mali) yielded fibres that are used in local handicraft of inexpensive articles. Chairs made of branches from Combretum micranthum G.Don and lignified petioles from Borassus aethiopium Mart. On one occasion, ropes made of baobab (Adanosia digitata; bark).In comparison, synthetic ropes could be up to three times more expensive. Bundles of the grass Panicum subalbidum Kunth, which sold as brooms (Gunnar Gusted et al., 2004; Josephine Yaméogo et al., 2007).

5.2.Food : The important NTFPs for local households in Mali and Benin are baobab leaf and fruit products, shea butter (cooking oil) from Vitelleria paradoxa nuts, and soumbala, which is a fermented paste made of seeds of Parkia biglobosa (Jacq). Ground baobab seeds are sometimes added to the soumbala. Honey is most often collected from bees living in baobab trees, either in natural holes or in hives. Similar to honey, baobab fruit powder was among the highest priced NTFPs in the market. Wholesale dealers also bought large amounts of fruits of Tarmindus indica Linn and Zizipus mauritania Lam. While the latter are appreciated for their apple-like taste, the nutritious tamarind juice is one of the most popular beverages in Mali. Gum arabic from Acacia seyal is also mainly an export product, but occasionally, is consumed locally as a snack (Kathrin Schreckenberg, 1999; 
Gunnar Gusted et al., 2004; Ræbild et al., 2011)

5.3.Medicinal: Concerning the baobab tree, the fruit appeared to be the plant part with the highest number and frequency of medicinal uses, e.g., the pulp crushed into water is often prescribed against infant diarrhoea. Uses of leaves and bark were also mentioned. (Gunnar Gusted et al, 2004; Gueye Mathieu and Diouf Meissa, 2007)

\section{Main challenges to parkland agroforestry.}

Although parkland agroforestry in West Africa have enormous beneficial products and services to the communities; there are many natural and artificial challenges in managing and utilizing them in sustainable manner. Some of the main challenges

According Gijsbers et al., (2003) in Burkina Faso, Survival rate of seedlings poor due to combined effect moisture stress and browsing, careless field clearing and weeding, and the presence of seedlings seemed to be determined mainly by moisture availability, seed availability and fruit exploitation.

The lack of knowledge and tradition in managing indigenous parkland trees and the slow growth and vulnerability of indigenous fruit tree seedlings remains a major factor discouraging farmers from fencing and protecting them (Emilie Smith, 2010). And Kathrin Schreckenberg (1999) also confirmed that the main challenge for parkland trees being cleared from the farmlands is due to the slow growth rate to provide yield and incapability of competing with other agricultural crops and improved exotic fruit trees.

Absence of market, processing technologies was also discouraged farmers to gain reasonable income and to be motivated to conserve and manage the parkland trees (Boffa, 1995; Bayala et al, 2011) and tree right for the products of parkland agroforestry (Boffa et al, 1999).

Land and tree tenure were other problems according to Fifanou et al (2011) and Poudyal, (2011) farmers who loan land are not allowed to grow woody species in it.

Land use and farming system such as intensive cultivation, weeding and institutional arrangement affected parkland tree diversity (Bayala et al., 2011; Ræbild et al., 2011) and the promotion of cash crops such as cotton, ground nut and maize led to degradation of Parklands (Boffa, 1995).

There is also incompatibility of trees in farmlands with crop yields according to Osman et al (2011) in Burkina Faso, agro forestry systems crop yields under trees are often low compared to outside. Cow pea sole crops had significant grain yield losses of up to $21 \%$ under trees compared to outside, and pearl millet yield was reduced up to $67 \%$ under trees.

And the other pressing challenge sahlean farmers faced is anthropogenic climate change has significant consequences for the sustainability and productivity of parkland agroforestry ecosystems upon which millions of smallholders in the tropics depend and that provide valuable global services (Dawson, 2010).

\section{Conclusion}

Parklands agrofrestry have many desfinitions according to habitat;parklands as scattered multipurpose trees occur in cultivated or fallowed fields (Pullan, 1974; Nair, 1985). From the ecological and economical perspective parklands: parklands are land-use systems in which woody perennials are deliberately preserved in association with crops and/or animals in a spatially dispersed arrangement and where there is both ecological and economic interaction between the trees and other components of the system (Bonkoungou et al., 1994).

In West Africa there is strong and longstanding scioecological interaction of farmers and parklands as anthropogenic landscapes with a rational land use system developed by farmers over many generations and those farmers select and protect tree species to diversify production for subsistence and income as well as to minimize environmental risks related to climatic variability (Boffa, 1995; Kathrin Schreckenberg, 1999; Boffa, 2000; Maranz and Wiesma, 2003; Bayala et al., 2011; Marius RM Ekué et al., 2010).

Parklands occupy a vast land area, representing a large part of the agricultural landscape under subsistence farming in the tropics and constituting the predominant agroforestry system in semi-arid West Africa (Nair, 1993; Bonkoungou et al., 1994).

Agroforestry parklands have high contribution of provision services and means of livelihood stragtegy in West African Sahel where the majority rural population is subsistence farmers select for certain functions for fodder production, food production, high quality wood, soil fertility maintenance, medicinal, income generation (Ibrahima D. and Malaïny D. 2004; Fifanou et al., 2011)

Agroforestry parklands also have high contribution to the conservation of biodiversity through in situ conservation of tree species on farm, reduction of pressure on remnant forests, and the provision of suitable habitat for a number of plant and animal species on farmland (Vodouhe Fifanou et al., 2011; Atta-Krah et al., 2004; McNeely and Schroth 2006; Acharya, 2006). And parklands also have in beneficial role in soil fertility improvement, medicinal values, cultural values and climate change mitigation.

Although parkland agroforestry in West Africa have enormous beneficial products and services to the 
communities; there are many natural and artificial challenges in managing and utilizing them in sustainable manner.Some of the major ones are drought and insufficient moisture for seedlings survival an/or regeneration.

Landuse change to intensive farming and few cash crops and total removal of scattered trees and due to the slow growth rate of indigenous trees they are being substitued by exotic and fast grwing trees.And Absence of market, processing technologies were also discouraged farmers to gain reasonable income and to be motivated to conserve and manage the parkland trees (Boffa, 1995; Bayala et al., 2011 ).

Land and tree tenure were other problems according to Fifanou et al (2011) farmers who loan land are not allowed to grow woody species in it.There is also incompatibility of trees in farmlands with crop yields according to Osman et al (2011) as shown in Burkina Faso, agro forestry systems crop yields under trees are often low compared to outside.Climate change is also great challenge to Sahlian parkland agroforestry systems.

In summary parkland agroforestry in West Africa covers wide part of the agricultural landscapes providing enormous services and products to the farming communities of the region and this could be an evidence for agricultural landscapes of the reservior of biodiversity especially trees and shrubs, and the socioecological interaction evolved across many generations played an important role to happen the existence of parkland agroforestry and giving recognition to those people is vital to understand and to exploit the knowledges and experiences of what is the motivation that enable them to conserve the parkland to various community parts and ethinic groups.

And the experinces of the West African parkland management is very crucial to their counterparts farming community in East Africa where predominatly engaged in agricultural activities and the East Africa farmers have suffered from recurrent drought. Hence, the best practices accumulated in West Africa have to be transfered to East Africa through linking the agroforestry expertes and even the farmers of the two regions.

\section{References}

Acharya, K.P. (2006). Linking trees on farms with biodiversity Conservation in subsistence farming systems in Nepal. Biodiversity Conservation 15:631-646

Ard, G.L. (2003). 'Diversity makes a difference'Farmers managing inter- and intra-specific tree species diversity in Meru Kenya,p.37

Asako, T., Ramachandran, N. and Vimala, D.N.(2007). Carbon stock and sequestration potential of traditional and improved agroforestry systems in the West African Sahel.

School of Forest Resources and Conservation, 118 Newins-Zeigler Hall, P.O. Box 110410, Gainesville, FL 326110410, United States).

Atta-Krah, K., Kindt, R., Skilton, JN. and Amaral, W. (2004). Managing biological and genetic diversity in tropical agroforestry.Agroforest Syst 61:183-194

Bayala, J., Teklehaimanot, Z. and S. J. Ouedraogo,(2002), Millet production under pruned tree crowns in a parkland system in Burkina Faso School of Agricultural and Forest Sciences, University of Wales, Bangor, Gwynedd, LLL57 2UW, Uk.

Bayala, J., Kindt, R., Belem, MC.and Kalinganire, A. (2011). Factors affecting the dynamics of tree diversity in agroforestry parklands of cereal and cotton farming systems in Burkina Faso New Forests, Volume 41, Issue 3, May 2011, Pages 281-296

Belem M., Bayala, J. , Kalinganire, A. (2011). Defining the poor by the rural communities of Burkina Faso: implications for the development of sustainable parkland management Agroforestry Systems, 2011, Pages 1$16: 12$

Bonkoungou, E.G., Alexandre, DY., Ayuk, E.T., Depommier, D., Morant, P. and Ouadba, JM. (1994). Agroforestry parklands of the West African semi-arid lands. Conclusions and recommendations of an international symposium, ICRAF/SALWA, 25-27 Oct. 1993, Ouagadougou, Burkina Faso. 18 pp.

Boffa, JM. (1995). Productivity and management of agroforestry parklands in the Sudan zone of Burkina Faso, West Africa. Ph.D. Purdue University, 1995, 101 pages; AAT 9622671.

Boffa, JM. (1999). Agroforestry parklands in sub-Saharan Africa. AGROFORESTRY SYSTEMS Volume 50, Number 2, 169-170

Boffa, JM. (2000). West African agroforestry parklands: Keys to conservation and sustainable management FAO, Intl. Plant Genetic Resource Institute.

Christine, O. and Sokpon, N. (2008). Traditional agroforestry systems as tools for conservation of genetic resources of Milicia excelsa Welw. C.C. Berg in Benin

Coulibaly, B. (1999). Evaluation du potentiel agricole de la filière mangue en 3e région. (preliminary). Agricultural sector promotion agency. Mali. $67 \mathrm{pp}$

Dawson, I.K., Vinceti, B., Weber, J., Neufeldt, H., Russell, J., Lengkeek, A.G., Kalinganire, A., Kindt, R., Lillesø, JP.B., Roshetko, J. and Jamnadass, R.(2010). Climate change and tree genetic resource management: Maintaining and enhancing the productivity and value of smallholder tropical agroforestry landscapes. A review Journal

Agro forestry Systems, Volume 81 
Emilie Smith. (2010). local knowledge of natural regeneration and tree management in Sahelian Parklands' North of Tominian, MALI Master of Science thesis (Masters) in Agroforestry Bangor University.

Faye, M.D., Weber, J.C., Mounkoro, B.and Dakouo, J.M. (2010). Contribution of parkland trees to farmers' livelihoods: A case study from Mali Development in Practice Volume 20, Issue 3, May 2010, Pages 428-434

Fifanou, V.G., Ousmane, C., Gauthier, B. and Brice, S.(2011) Traditional agroforestry systems and biodiversity conservation in Benin (West Africa) Agroforestry Systems, Volume 82, Issue 1, May 2011, Pages 1-13 .

Gueye, M. and Diouf, M. (2007). Traditional Leafy Vegetables in Senegal: Diversity and Medicinal Uses African Journal of Traditional, Complementary and Alternative Medicines, Vol.4, No. 4, 2007, pg. 469 - 475.

Gunnar Gustad, Shivcharn. S.Dhillion and Daouda Sidibi (2004). Local us e and cultural and economic value of products from trees in the parklands of the Municipality of Cinzana, Mali.Economic Botany 58(4):578587. 2004

Gijsbers, H.J.M., Kessler, J.J. and Knevel, M.K. (2003). Dynamics and natural regeneration of woody species in farmed parklands in the Sahel region (Province of Passore, Burkina Faso). Forest Ecol. Manage. 64 (1994) $1-12$

Ibrahima Diédhiou and Malaïny Diatta (2004). Farmers' perceptions of the role of trees in the agricultural landscape of the Sudanian zone of Senegal: the case of Medina Yoro Foulah in Upper Casamance. Regional institute,Australian Society of Agronomy.

Joséphine Yaméogo, Mamounata Belem/Ouédraogo, Jules Bayala, Makido Bertin Ouédraogo et Sita Guinko (2007). Uses and commercialization of Borassus akeassii Bayton, Ouédraogo, Guinko non-wood timber products in South-Western Burkina Faso, West AfricaBiotechnologie, Agronomie, Société et Environnement; ISSN 1370-6233, volume 12

Kalinganire, A., Weber, J. C., Uwamariya, A. and Kone, B. ( 2007) Improving Rural Livelihoods through Domestication of Indigenous Fruit Trees in the Parklands of the Sahel in Indigenous Fruit Trees in the Tropics: Domestication, Utilization and Commercialization (eds F.K. Akinnifesi et al.) CAB International

Kathrin Schreckenberg (1999). Products of a Managed Landscape: Non-Timber Forest Products in the Parklands of the Bassila Region, Benin Global Ecology and Biogeography,Vol. 8

Jonsson, K., Ong, C. K. And Odongo, J. C. W.(1998). Influence of scattered trees nere and karite trees on microclimate,soil fertility and millet yield in Burkinafaso Expl Agric. (1999), volume 35

Marius RM Ekué, Brice Sinsin, Oscar Eyog-Matig and Reiner Finkeldey, (2010). Uses, traditional management, perception of variation and preferences in ackee (Blighia sapida K.D. Koenig) fruit traits in Benin: implications for domestication and conservation Journal of Ethnobiology and Ethnomedicine 2010, 6

Martinez S. and wieseman Z., (2003). Evidence for indigenous selection and distribution of the shea tree, Vitellaria paradoxa, and its potential significance to prevailing parkland savanna tree patterns in sub-Saharan Africa north of the equator. Journal of Biogeography 30(10):1505 -1516

Mcneely, JA. and Schroth, G. (2006). Agroforestry and biodiversity conservation - traditional practices, present dynamics, and lessons for the future. Biodiversity and Conservation (2006) 15:549-554

Nair, P.K.R. (1993). An introduction to Agroforestry. Kluwer Academic Publishers,Dordrecht, the Netherlands

Otegbeye, G.O. \& Olukosi, J. (1993). Farmed parkland agroforestry system in Katsina State of Nigeria. Paper presented at the 'International symposium on agroforestry parklands in the semi-arid lands of West Africa'. Actes du séminaire international, ICRAF/IRBET/CILSS/LTC, Ouagadougou, Burkina Faso, 25-27

Osman, A.N., Ræbild, A., Christiansen, J.L., Bayala, J.(2011). Performance of cowpea (Vigna unguiculata) and pearl millet (Pennisetum glaucum) intercropped under parkia biglobosa in anagroforestry system in Burkina Faso. African Journal of Agricultural Research Volume 6

Peter Poschen,(1986). An evaluation of the Acacia albida-based agroforestry practices in the Hararghe highlands of Eastern Ethiopia Agroforestry systems, Volume 4,Number 2, 129-143

Poudyal, M. (2011), Chiefs and trees: Tenures and incentives in the management and use of two multipurpose tree species in agroforestry parklandsin Northern Ghana. Society and Natural Resources, Volume 24,

Pullan, R.A. (1974). Farmed parklands in West Africa. Savana,3 ,119-152

Ræbild, A., Hansen, U.B. , Kambou, S. (2011). Regeneration of Vitellaria paradoxa and Parkia biglobosa in a parkland in Southern Burkina Faso. Agroforestry Systems ,2011, Pages 1-11

Reynes, M. and Odoux. E. (1999). La transformation de la mangue pour le compte du Centre Agro-Entreprise. Mission Report 7 - 15 December 1999. CIRAD. 17 pp.

Rudat, H., Nyamekye, A.L., Kasei, C.N., Frey, E. \& Peiler, E. 1996. The role of farmed parklands in northern Ghana's agriculture.

Schroth G, Fonseca GAB, Harvey CA, Gascon C, VasconcelosHL, Izac A-MN (2004), Agroforestry and biodiversity conservation in tropical landscapes. Island Press, Washington, $523 \mathrm{p}$

Takimoto, A., Nair, P.K.R., Alavalapati, J.R.R. (2008). Socioeconomic potential of carbon sequestration through agroforestry in the West African Sahel EARTH AND ENVIRONMENTAL SCIENCE, Volume 13 